\title{
Designing and Manufacturing Tubular Solar Dryer for Drying Okra
}

\author{
Hassan Hadi Mehdi AL Rubaiy \\ Food science department - Agriculture college - Basrah University - Iraq
}

\begin{abstract}
An indirect tubular solar dryer for drying Okra was designed and manufactured in a food engineering workshop at the College of Agriculture, Basrah University. The dryer consists of a tubular solar collector with a dimension of $0.3 \mathrm{~m} \times 1.5 \mathrm{~m}$ a chimney and tubular met at mesh. The solar collector comprises a drying tube made of galvanized iron and has a capacity of $5 \mathrm{~kg}$. The results of the tubular solar dryer and of natural solar drying were compared during the study period. Solar radiation intensity increased as the morning passed, reaching the highest level at midday $\left(780.55 \mathrm{~W} / \mathrm{m}^{2}\right)$. The drying efficiency by tubular solar dryer was found higher than the natural solar drying, reaching $55 \%$ and $40 \%$ respectively. The average temperature in the drying tube reached $55^{\circ} \mathrm{C}$ at $1: 00 \mathrm{PM}$, and the air temperature was $41^{\circ} \mathrm{C}$. By 4:00 PM, the moisture content of dried Okra decreased from $80.80 \%$ to $16.32 \%$ using the tubular solar dryer and $28.44 \%$ using natural solar drying.
\end{abstract}

Keywords: Solar tubular dryer , Drying Okra, Solar drying

DOI: $10.7176 / \mathrm{FSQM} / 90-03$

Publication date:September $30^{\text {th }} 2019$

\section{Introduction}

The fresh foodstuffs contain different water proportions . Those with high moisture content are susceptible to damage due to the growth of microorganisms in the water solutions and their use of the components of these substances for feeding. Removing of moisture from foodstuffs saves them from damage for a long period of time, and the foodstuffs can be consumed by adding water or water. This process is called drying (1)

Drying prevents food damage, such as fruits, vegetables, cereal crops, meat, fish, and milk by stopping the activity of bacteria, fermentation, and enzymes. Foodstuffs preserved by drying have enhanced flavor and nutritional value , and they are lightweight and easy to store and prepare (9), (15). Drying processes have been known as a food preservation method since ancient times . Natural solar drying is one of the oldest conservation methods known to humans, used by the people in Arab countries to dry fruits and vegetables from one season to another . This method needs areas with high temperatures, low moisture, and no rain during the drying period (15).

The natural solar drying method with changes in the treated foodstuffs, such as wear related to different in weather conditions and pollution of microorganisms, dust and insects. All of these lead to reduced nutritional value. In addition, this process requires a large area and a relatively long time for drying, so it is not fully exploited for economic reasons, especially on a large scale (11), (20). Solar energy is one of the cheapest and most abundant energies in Iraq. It is clean, environmentally friendly with no residual pollutant and an alternative and renewable energy. Solar radiation energy can be used properly in drying processes through converting into thermal energy by using a solar collector. This method is an effective means to dry food which, in turn, results in a homogeneous product with no shrinking compared with other drying processes, such as using electric dryers and natural solar drying. In addition, moisture decreases as food stays longer in the solar collector.

Al Hilphy (2) developed a solar dryer for fruits and vegetables, and he found that the cleaned Okra with the solar dryer gave the best results in terms of qualities and properties compared with the cleaned Okra using traditional methods. The present study aims to design and manufacture of the tubular solar dryer for drying Okra. The combined drying room and solar collector are independent of external conditions.

\section{Materials and Methods:}

A tubular solar dryer was designed and manufactured in a food engineering workshop, Agriculture college, Basrah University, It used for drying Okra ( Hibiscus esculents L.) This is composed of the following parts: (Fig. 1)

\subsection{Iron structure :}

The iron structure was manufactured from the angle iron with $0.05 \mathrm{~m} \times 0.05 \mathrm{~m}$ dimensions with a vertical base of $1.50 \mathrm{~m}$ length and a width of $0.30 \mathrm{~m}$. It was supported by a second base, a length of $1.40 \mathrm{~m}$ and a width of $0.30 \mathrm{~m}$ and a height of $0.90 \mathrm{~m}$ from behind and the height of $0.30 \mathrm{~m}$ on the front, which makes the structure takes the shape of the triangle and the corner and at a tilt angle of $30^{\circ}$ (Fig. 1). This base is provided with four small tires, each of which is $0.20 \mathrm{~m}$, for easy movement and transfer. The vertical base is designed in the shape of an incubator whose function is to contain and install the solar collector. For the purpose of increasing the durability of the iron structure, it was provided with angular iron cutters and was slanted in a diagonally. 


\subsection{Solar collector:}

Solar collector was manufactured for the tubular dryer, it supplies the needed thermal energy to reach the desired temperature. The solar collector consists of the following parts:

A. wooden structure:

Whitewood was used in the manufacture of the wooden structure, which is a rectangular structure of $1.50 \mathrm{~m}$ length, a width of $0.30 \mathrm{~m}$, a depth of $0.25 \mathrm{~m}$, and the thickness of $0.015 \mathrm{~m}$. It's consist of four wooden cutters length of $0.30 \mathrm{~m}$ and width $0.15 \mathrm{~m}$ and $0.015 \mathrm{~m}$ thickness for the purpose of increasing the durability of the wooden structure. The nearby base from the wooden cutters was covered with wooden plates of $1.50 \times 0.30 \mathrm{~m} 2$ diameter and thickness of $0.004 \mathrm{~m}$.

B. The Insulation:

A $0.05 \mathrm{~m}$ thickness of foam insulation was used to reduce the amount of heat loss from the solar collector. The essential function of using insulation to isolate the drying tube from the outside and thus not to leak the heat energy acquired abroad (20). The insulator was placed inside the wooden structure at a height of $0.08 \mathrm{~m}$ from the base. It was proved by an internal wooden frame with special bolts. Internal cover made of reflective aluminum plates was put on the inter-insulator.

C. Drying tube :

A drying tube was made of a galvanized iron tube with a length $1.66 \mathrm{~m}$, a thickness of $0.015 \mathrm{~m}$ and a diameter of $0.10 \mathrm{~m}$. It has two openings on both sides and is designed with two airtight covers, one of which has a valve, and a hole above the tube penetrates the glass cover. (Fig.1)

The drying tube was painted from the outside in dark black with local dyes. The dorsal tube was fixed directly on the insulator inside the wooden structure by means of a glove and special screws. A cylindrical clip with a diameter of $0.09 \mathrm{~m}$ was manufactured for the purpose of placing the Okra to be dried in it and then pushed inside the drying tube.

D. Glass cover:

The normal glass was used for covering the solar collector with a thickness of $0.004 \mathrm{~m}$. Glass cover dimensions are $1.45 \times 0.25 \mathrm{~m} 2$. The glass cover was installed at $0.07 \mathrm{~m}$ from the absorption plate inside the wooden structure by Wooden framed frame with aluminum plates. White silicon was used as an adhesive for the glass cover and to prevent air from entering the vacuum. The solar collector was Installed into the iron structure by special screws. E. The temperature gauge:

The electronic temperature gauge of modal XMTD-2301was used to measure the drying tube temperature, which is installed on the upper right side of the dryer with a double thermometer attached directly on the inter drying tube. A Constantine- copper thermocouples (made by Bollix England company) was distributed on the glass covered and mercury thermometers were used to measure the ambient temperature.

F. Solar radiation energy meter:

The CM12-type of pyranometer (made by Kipp and Zonen, Holland company) was fixed on the upper left of the device and at a 30-degree angle to measure the energy of solar radiation falling on the surface of the solar collector and its readings were taken using a digital voltmeter.

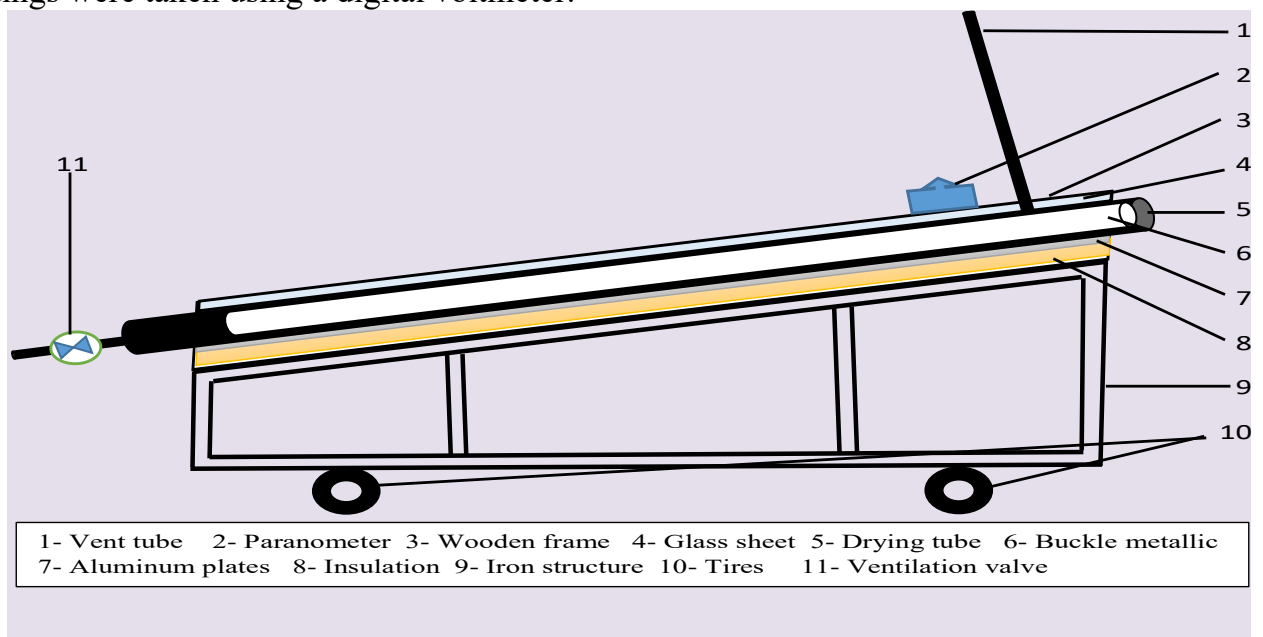

Figure (1) : Lagout of the solar tubular dryer

\section{Mechanical work:}

A certain amount of Okra, category (Hibiscus esculents L.) was taken and it was blanched for 3 to 4 minutes with hot water for the purpose of stopping enzymes, especially Ascorbic acid Oxidase, which is found in vegetables and fruits to prevent darkness of vegetables and fruits dried (8) It's divided into two parts. The first penalty was 
discharged in the traditional way by placing Okra in metal trays and exposing them to the solar rays with continuous flipping periods and then placed in the shade until dry. The second penalty was placed in the metal clamp and was inserted into the drying tube in the solar dryer. Three replicates were used in the experiments and studied the parameters like the following:

\section{1 drying time:}

The time required for the drying was measured for the two methods based on the number of solarny hours, the study was identified from 9:00 am to 4:00 pm and the measurement was adopted for each hour.

\subsection{The moisture:}

The relative moisture in the drying room and outside was measured by moisture device, type of normal (made by SOLARDO company, German). The moisture of the fresh Okra was measured before and after drying at $105^{\circ} \mathrm{C}$ until the stable weight (2). Moisture content was estimated on a wet basis (\%) in discharged Okra at different intervals by measuring the weight at each specific time period (6).

\subsection{Water activity:}

Water activity of the Okra was calculated using the following relationship (16).

When :

$$
\alpha=\frac{M e}{100}
$$

$\alpha$ : Water activity .

Me: Equilibrium Moisture content \% .

\subsection{Drying efficiency:}

The drying efficiency was calculated from the following relationship (14):

When:

$$
\eta_{d}=\frac{Q_{D}}{I_{T} A_{C}} \times 100
$$

$\eta_{d}$ : Drying efficiency (\%) .

Qd: The energy needed for drying $(\mathrm{kJ} / \mathrm{sec}$.)

$I_{T}$ : Solar radiation energy $\left(\mathrm{W} / \mathrm{m}^{2}\right)$

Ac: Solar collector area $\left(\mathrm{m}^{2}\right)$.

3.5 Measurement of rehydration:

The rehydration was measured according to Rangana's method (13) which was summed up as taking $10 \mathrm{~g}$ of dried material and putting in a glass flask, Then $100 \mathrm{ml}$ of distilled water was added and close it tightly and heated for 3-4 minutes, then boiled for 5 minutes and then the excess water is filtered then weighted, after that the rehydration was calculated by the following relationship

Rehydration $=$ The weight of the sample after rehydration $\backslash$ The weight of the sample before rehydration .

\section{6 statistical analysis:}

The complete random design (C.R.D.) was used for factorial experiments $(8 \times 2)$, it used two methods of drying( the conventional method and the drying of the tubular dryer) and the eighth time $(9,10,11,12,13,14,15,16)$. The data were analyzed statistically by the statistical program Spss (17). The studied factors were tested using a less significant difference (L.S.D.) at a probability level of 0.05 .

\section{Results and discussion}

Figure (2) shows that the solar radiation energy increased as daylight hours passed until $12 \mathrm{NN}$. The highest level of solar energy was $780.55 \mathrm{~W} / \mathrm{m}^{2}$ and then decreased to610.13 W/ $\mathrm{m}^{2}$ at 4:00 PM due to the earth's rotation around its axis. The solar angles(zenith, altitude and azimuth) changed with daylight hours, The reduction of level to zero at midday and increase to maximum values at sunrise and sunset as well as the angular change with daylight hours coincide with the results of Duffie and Lunde (10). This finding agrees with AL-Hilphy (4), AL-Rubai'y (5), Krauter and Ochs (12), Singh (18), Hilphy (2) who asserted that solar radiation energy increases with daylight hours and reaches the maximum value at midday, . AL-Hilphy (3) reported that the rate of solar radiation energy in Basrah City was $740 \mathrm{w} / \mathrm{m}^{2}$ in 2009. 


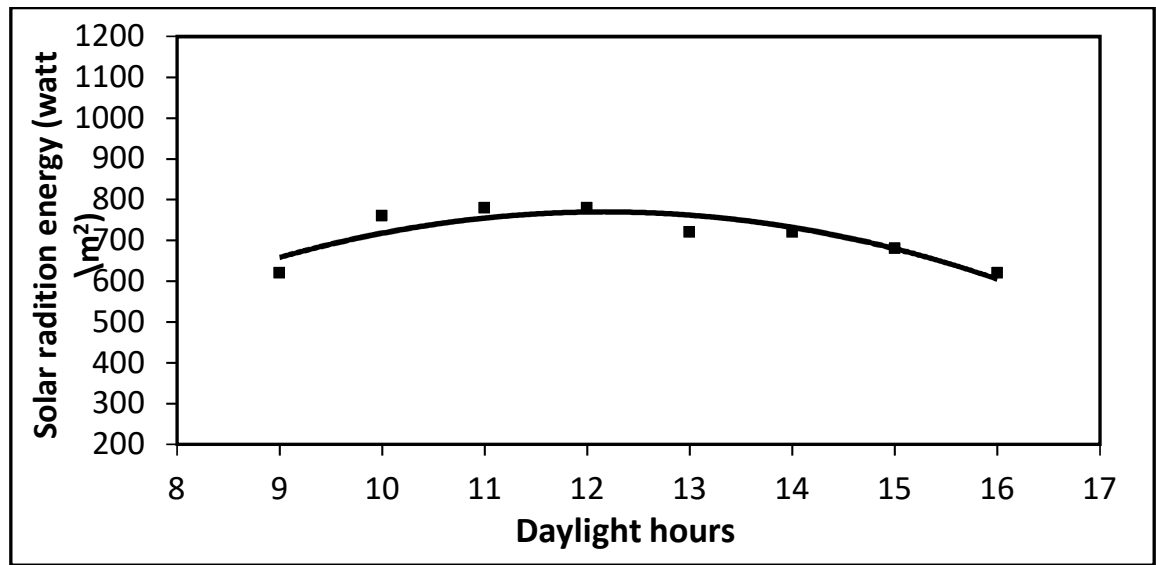

Figure (2): The mean of solar radiation energy during the daylight hours for day (198) in September.

Table (1) indicates that the temperature significantly $(\mathrm{p} \leq 0.05)$ increased in the solar dryer with the passing of daylight hours and reached the maximum value at 1:00 PM $\left(55^{\circ} \mathrm{C}\right)$. Afterwards, temperature decreased due to the continued heat transfer to the drying tube which was isolated from external elements. The temperature was retained at 1:00 PM as a result of the heat gathered inside.

Table (1): Recorded temperature of atmosphere and tubular dryer during daylight hours for day (198) of September.

\begin{tabular}{|c|c|c|}
\hline Time (hour) & $\begin{array}{c}\text { temperature of } \\
\text { atmosphere }\left({ }^{\circ} \mathrm{C}\right)\end{array}$ & $\begin{array}{c}\text { temperature of tubular } \\
\text { dryer }\left({ }^{\circ} \mathrm{C}\right)\end{array}$ \\
\hline 9 & 28 & 40 \\
\hline 10 & 33 & 46 \\
\hline 11 & 40 & 50 \\
\hline 12 & 41 & 54 \\
\hline 13 & 41 & 55 \\
\hline 14 & 40 & 55 \\
\hline 15 & 38 & 53 \\
\hline 16 & 35 & 51 \\
\hline The mean & 37 & 50.5 \\
\hline L.S.D. & 3.2 & 2.4 \\
\hline
\end{tabular}

Moisture assessment is one of the most important and widespread analyses in laboratory tests because its results are important for consumers and food manufacturers alike. The importance of moisture assessment to maintain food quality includes prevention of high moisture in the grain,which leads to fungi growth as well as insect damage and germination. In addition, the proportion of moisture increases the speed of the reactions in the aromatic dried fruits and vegetables. The moisture proportion significantly decreases from $93 \%$ to $20 \%$ for fruits and $95 \%$ to $64 \%$ for vegetables and $10.7 \%$ for dried vegetables $(8)$.

Table (2) shows that the relative moisture in the drying tube is much lower than that in the atmosphere. This outcome is due to the high temperature in the drying tube, and the increase in air movement causes water vapour to exit from the upper hole of the drying pipe. Thus, the solar tubular drying is clearly superior over natural solar drying in terms of reduced levels of moisture or water activity. By using natural solar drying, the Okra was exposed to changing environmental conditions, such as increased in the evening, and regained water from the atmosphere. By comparison, the tubular solar dryer depends on solar radiation energy available from 9 AM to 4 PM and then stops until the next day. During this period, the Okra in the drying tube did not absorb moisture from due to its isolation from the atmosphere.

The temperature changes with daylight hours supports the findings of AL-Hilphy (2), who confirmed that solar drying removes a higher amount of moisture compared with natural solar drying. The results showed that the moisture content of the fresh Okra was $80.80 \%$ before drying. After a drying period of 1-2 days by using the solar dryer and 2-3 days by natural solar drying the moisture level decreased to $16.32 \%$ and $28.44 \%$ by at $4: 00$ $\mathrm{PM}$, respectively.

Dalali and Hakim (8) indicated that the moisture content of fresh Okra is $87.1 \%$. Their drying process resulted in the nearly full drying of the Okra to a moisture content of $3 \%$ using the solar dryer for 1-2 days, whereas natural solar drying took 2-4 days to reach a moisture content of 7\%. This result agrees with Brennand (7) who confirmed that drying Okra needs 1-3 days by using the solar dryer and 3-5 days through natural drying. 
Table (2): Relative moisture in the dryer, moisture content and water activity of the cleaned Okra in the dryer tube and natural drying during daylight hours for a day (198) of September.

\begin{tabular}{|c|c|c|c|c|c|c|}
\hline \multirow[b]{2}{*}{$\begin{array}{l}\text { Time } \\
\text { (hour) }\end{array}$} & \multicolumn{2}{|c|}{ Moisture content $(\%)$} & \multicolumn{2}{|c|}{ Water activity } & \multicolumn{2}{|c|}{ Relative moisture $(\%)$} \\
\hline & $\begin{array}{c}\text { Tubular Solar } \\
\text { Dryer }\end{array}$ & $\begin{array}{c}\text { Natural Solar } \\
\text { Drying }\end{array}$ & $\begin{array}{c}\text { Tubular Solar } \\
\text { Dryer }\end{array}$ & $\begin{array}{c}\text { Natural Solar } \\
\text { Drying }\end{array}$ & $\begin{array}{c}\text { Tubular } \\
\text { Solar Dryer }\end{array}$ & Otmosphere \\
\hline 9 & $80.80 \pm 0.035$ & $0.03580 .80 \pm$ & $8080.0 \pm 0.0003$ & $0.00030 .8080 \pm$ & $48 \pm 2.64$ & $61 \pm 1.52$ \\
\hline 10 & $0.15069 .76 \pm$ & $0.10577 .45 \pm$ & $0.0015 \pm 0.6976$ & $0.00100 .7745 \pm$ & $2.6435 \pm$ & $2.0852 \pm$ \\
\hline 11 & $0.72060 .89 \pm$ & $0.95066 .78 \pm$ & $0.00720 .6089 \pm$ & $0.00956678 \pm 0$. & $1.5226 \pm$ & $2.52 \pm 40$ \\
\hline 12 & $0.27241 .20 \pm$ & $0.96052 .15 \pm$ & $0.00270 .4120 \pm$ & $0.00960 .5215 \pm$ & $2.0818 \pm$ & $2.64 \pm 35$ \\
\hline 13 & $0.10934 .12 \pm$ & $0.04041 .45 \pm$ & $0.00103412 .0 \pm$ & $0.00040 .4145 \pm$ & $1.5210 \pm$ & $1.5230 \pm$ \\
\hline 14 & $0.12826 .76 \pm$ & $0.09135 .88 \pm$ & $0.00120 .2676 \pm$ & $0.00090 .3588 \pm$ & $1.529 \pm$ & $1.5223 \pm$ \\
\hline 15 & $0.60019 .24 \pm$ & $0.06534 .22 \pm$ & $0.00600 .1924 \pm$ & $0.00060 .3422 \pm$ & $1.529 \pm$ & $1.3424 \pm$ \\
\hline 16 & $0.116 \pm 16.32$ & $0.210 \pm 28.44$ & $0.0011 \pm 0.1632$ & $0.0021 \pm 0.2844$ & $1.527 \pm$ & $1.11 \pm 25$ \\
\hline Mean & $0.10043 .63 \pm$ & $0.09052 .14 \pm$ & $0.00104363 \pm 0$. & $0.00090 .5214 \pm$ & $20.25 \pm 1.68$ & $36.52 \pm 1.78$ \\
\hline L.S.D & 12.89 & 10.11 & 0.1289 & 0.1011 & 11.22 & 10.08 \\
\hline
\end{tabular}

Figure (3) illustrates a drying efficiency of $56 \%$ in the solar tubular dryer and $40 \%$ using the natural solar drying method. The reasons for the higher drying efficiency of the tubing dryer include the higher temperature in the drying tube and the ability to convert the solar radiation energy to thermal energy. Furthermore, in the natural solar drying method the Okra was placed in trays under direct sunlight and needed a larger surface area for the drying, whereas in the tubular solar dryer, the Okra was placed in special buckle figure (1) tilted at $30^{\circ}$ the angle following the slope of the solar collector. Thus, the hot air passes and evaporates moisture. The speed of dehumidification in the tubular dryer is greater than that of natural solar drying. All these factors combined to increase the drying efficiency.

This result is consistent with the result of AL- Hilphy (2), who confirmed that using a solar dryer to dry fruits and vegetables provides higher efficiency than natural solar drying. The drying efficiency of an indirect solarpowered dryer with forced flow reached $45 \%$ after two hours of drying time, which represented constant evaporation phase. Efficiency was also increased in terms of evaporation rate (19).

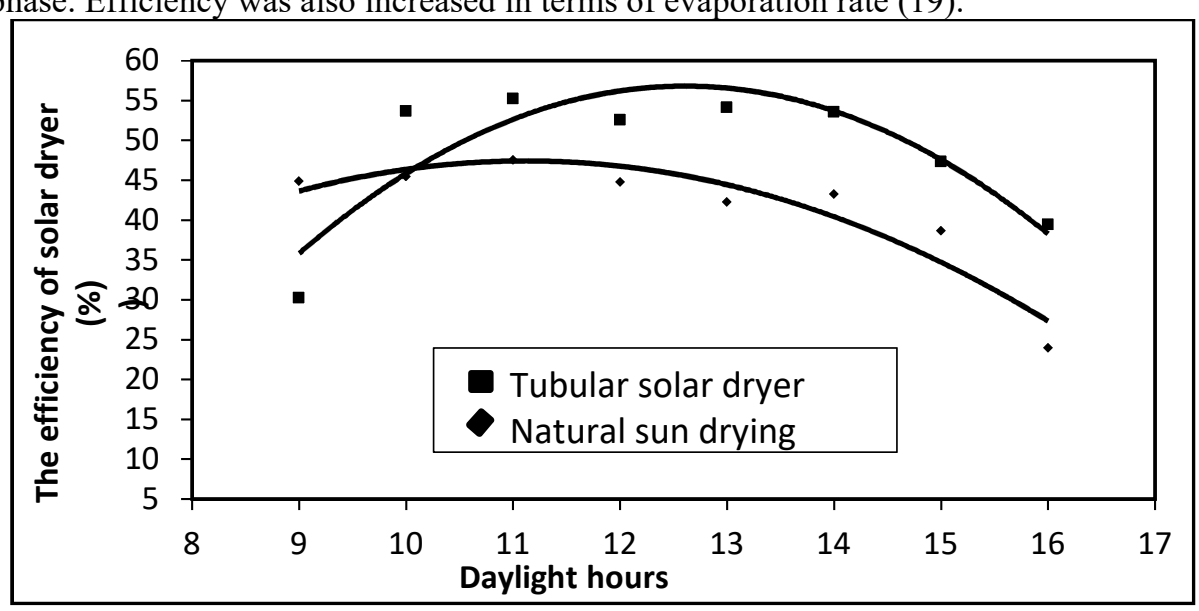

Figure (3): The mean of solar drying efficiency during daylight hours for day (198) in September.

Rehydration was 4.6 in the tubular solar powder samples which is higher than that natural solar drying at 3.9.
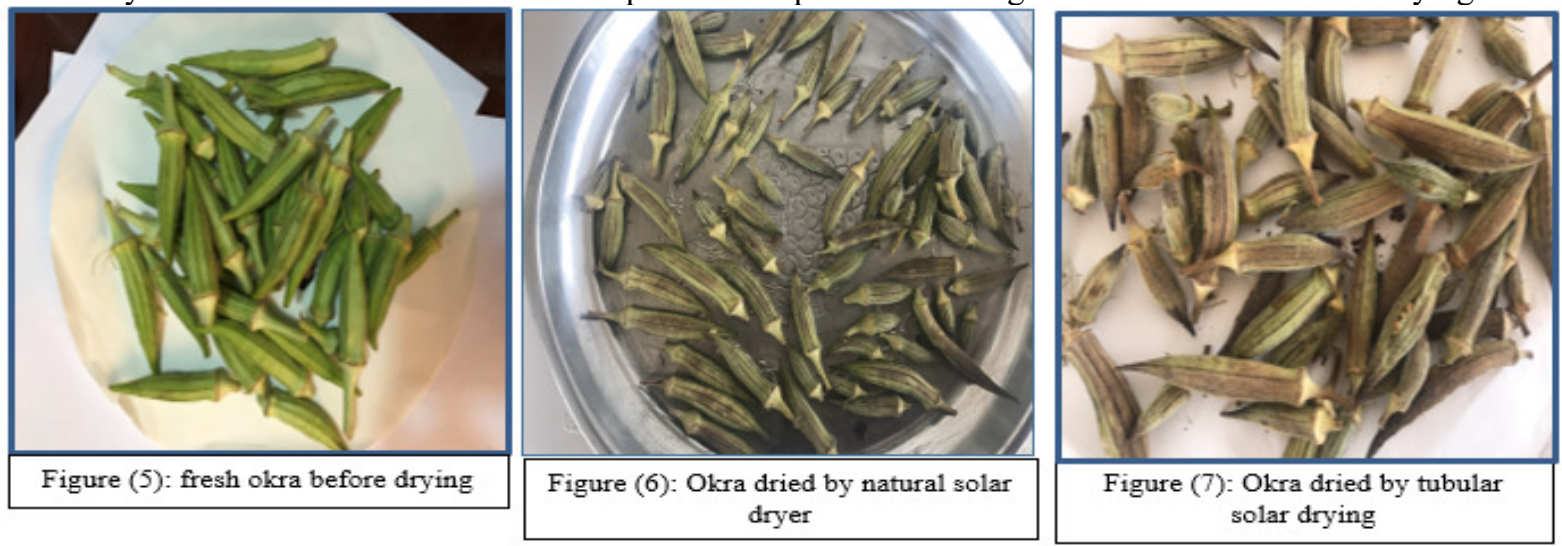


\section{CONCLUSIONS:}

The maximum solar radiation energy reached $780.55 \mathrm{~W} / \mathrm{m}^{2}$ at $12 \mathrm{NN}$. Okra was kept in the dark during the drying period. The efficiency of the tubular solar dryer was $56 \%$, whereas that of natural solar drying was lower at $40 \%$. The moisture of dried Okra was reduced to $16.32 \%$ in the tubular solar dryer, lower than that by using solar drying $(28.14 \%)$. The rehydration rate of dried Okra by using the tubular solar dryer was higher at $4.6 \%$ compared with that through natural solar drying at $3.9 \%$.

\section{Acknowledgement:}

I would like to thank Food science department, Agriculture college, Basrah University for providing the workshop to complete the manufacturing apparatus. I was extremely grateful to Prof. Asaad R.S. Al-Hilphy for him advise and continuous support.

\section{References}

1. AL-Dahaan, A. H. S. (1981), "Food and dairy plants engineering. Sima - Rotomaca 77200 Press , Torchy, France .

2. AL- Hilphy, A. R. (2006), "Development of a solar dryer and studying its efficiency in drying of same fruits and vegetables .ph.D. Thesis, College of Agriculture, University of Basrah, Iraq .

3. AL- Hilphy, A. R. (2010), “ Food engineering by solar energy”, AL-Zahra press. Basrah, Iraq . 400 p.

4. AL- Hilphy, A. R. (2013), "A theoretical and practical study for the incident solar radiation intensity in the Basrah province (South of Iraq) ", IOSR Journal of Engineering, 3(9) : 25-35.

5. AL-Rubai'y, H. H. M. (2010), "Designing and manufacturing milk pasteurization device by solar energy and studying its efficiency", ph.D. Thesis, College of Agriculture, University of Basrah. Basrah , Iraq.

6. A.O.A.C: Association of Official Analytical Chemists (1984), "Official methode of analysis of the association of official analytical Chemist", $14^{\text {th }} \mathrm{ed}$., Arlington, Virginia , 22209 USA

7. Brennand, C.B. (1994), "Home drying of food", . Utah State University. Extension. (FN-330).

8. Dalali, B. K. and Hakim, S. H. (1987), "Food analysis", Dar Al Kutub Press. University of Al Mosul . Iraq.

9. David , E. W. V. (2000), "Solar dryer systems and the internet : Important resources to improve food preparation", International Conference on Solar Cooking . Kimberly-South Africa , $26^{\text {th }}-29^{\text {th }}$, Novomber.

10. Duffie , J.A. and Beckman, W.A. (1980), "Solar engineering of thermal", Processes , Willey - Interscience , New York .

11. Hassan, A. M. (1979), "Food industries principles", Dar Al - Jahed Press. Baghdad 184p.

12. Krauter , S. and Ochs , F. (2002), "An all - in - one solar home system”, R10 02 - world climate and energy events , January $6-11,2002$.

13. Rangana , S. (1973), "Manual of analysis of fruit and vegetable products", Tata Ma Graw - Hill publishing Company Ltd. New Delhi.

14. Saleh, T. and Sarkar, M.A.R. (2002), "Performance study of a PV operation forced convection solar energy dryer", The Technical Session of the $8^{\text {th }}$ International and Symposium for Renewable Energy Education (ISREE - 8) Orlando August 4-8. University of Florida, U.S.A.

15. Sebaii , A.A. ; Abaul-Enein , S. ; Ramadan , M.R. and EL - Gohary , H. (2002), "Experimental investigation of an indirect type natural convection solar dryer", Energy Convection and Management, 43 : 2251-2266.

16. Singh, S. ; Singh , P.P. and Dhaliwal, S.S. (2004), "Multi-shelf portable solar dryer", Renewable energy, 29 : 753-765.

17. SPSS: Statistical Package for the Social Sciences (2009), "Statistical Package for window", Ver. 17, O. Chicago, Spss, Inc.

18. Tiris , C. ; Ozbalta , N. ; Tiris , M. and Dincer , I. (1994), "Experimental testing of a new solar dryer", International Journal of Energy Research. $18: 483-49$.

19. Vlachos , N.A. ; Karapantsios , T.D. ; Balauktsis , A.I. and Chassapis , D.(2002), "Drying technology", 20 (5) : 1239-126.

20. Whillier, A. (1976), "Prediction of performance of solar collectors. In: Application of solar energy for heating and cooling of buildings", Jordan , R.C. and Liu , ASHRAE , GRP 170. 